AGRICULTURE AND BIOLOGY JOURNAL OF NORTH AMERICA

ISSN Print: 2151-7517, ISSN Online: 2151-7525, doi:10.5251/abjna.2011.2.3.462.470

(C) 2011, ScienceHu $\beta$, http://www.scihub.org/ABJNA

\title{
Litter fall and decomposition trend of jatropha curcas L. leaves mulches under two environmental conditions
}

\author{
Abugre, S. ${ }^{1}$ C. Oti-Boateng ${ }^{2}$ and M.F. Yeboah ${ }^{1}$ \\ ${ }^{1}$ Faculty of Forest Resources Technology, KNUST, Sunyani, Ghana. \\ ${ }^{2}$ Faculty of Renewable Natural Resources, KNUST, Sunyani, Ghana. \\ ${ }^{1}$ Corresponding author's Phone: +233209500070, Email: simabu2001@yahoo.com
}

\begin{abstract}
The study was conducted at the Faculty of the Forest Resources Technology, Sunyani, Ghana, with the objective of finding out the litter fall and the decomposition trend of Jatropha curcas leaf mulches. A $2 \mathrm{~mm}$ nylon mesh size fitted to stakes at $1 \mathrm{~m}$ above the ground was used to trap the leaf litter and their oven dry weights taken. Decomposition of Jatropha curcas leaf litter was assessed by placing $80 \mathrm{~g}$ fresh leaf in a $0.30 \mathrm{~m} \times 0.30 \mathrm{~m}$ nylon litter decomposition bags of $2 \mathrm{~mm}$ mesh size at two (2) different environmental conditions and records taken for four months. The results showed that the total quantity of litter produced in a year at different spacing were 2.27 ton/ha, 1.10 tons/ha and 0.79 tons/ha for $1 \mathrm{~m} \times 1 \mathrm{~m}, 2 \mathrm{~m} \times 1 \mathrm{~m}$ and $3 \mathrm{~m} \times 1 \mathrm{~m}$ respectively. The month of November had the highest litter fall $(508.8 \mathrm{~kg} / \mathrm{ha})$ for $1 \mathrm{~m} \times 1 \mathrm{~m}$. Jatropha curcas under open canopy had $97-99 \%$ of the leaf litter decomposing at the end of the experimental period (120 days) and a half life of 25 days. The concentration of carbon, nitrogen and phosphourus, calcium, magnesium and potassium did vary significantly over the four months period. On the basis of the results obtained Jatropha curcas leaf liter would not be good mulch but could be a source of nutrients.
\end{abstract}

Keywords: Decomposition, Jatropha curcas, litter fall, Open canopy, Closed canopy

\section{INTRODUCTION}

Decomposition is an important part of all life cycles both in the terrestrial and aquatic environment. Litter fall and litter decomposition are two essential means by which the nutrient pool in terrestrial ecosystems is maintained (Karmas, 1970). After leaves fall they build up on the forest floor creating a layer of nutrients and litter on top of the soil. This layer is not only important for food chain as it acts as food for many microscopic beings, but more importantly it acts as a way for recycling the nutrients back into the soil. As the leaves decompose, the nutrients are released back to the ground where it helps to feed vegetation in the surrounding area.

A comprehensive knowledge of the organic matter decomposition and nutrient release patterns from leaf litter maximizes soil sustainability and crop productivity (Mugendi et al., 1999). Planting tree species with high biomass production and rich in foliar and branch nutrient content can therefore play a major role in maintaining levels of soil organic matter in alley cropping systems (Young, 1997).

The Jatropha curcas L. plant is currently receiving a great deal of attention. It has been recognized as a source for medium viscosity plant oil that is easily converted to biodiesel with good product properties (Agarwal, 2007). The growing global biodiesel market has attracted investors and project developers to consider Jatropha curcas L. biodiesel as a substitute for fossil resources to reduce green house gas emissions. By promoting the integrated utilization of Jatropha plant, the Jatropha system can provide direct financial benefits to the rural economy. To achieve this, it is anticipated that large tracts of farmlands would be put into Jatropha curcas L. plantations. With scarcity of land due to increase in population, it is expected that Jatropha curcas will be grown with annual crops on the same piece of land in an agroforestry system.

The dynamics of litter production and decomposition are processes that replenish the soil nutrient pools, maintain soil life and thus ensure sustainability to agroforestry systems (Isaac and Nair, 2006). The rates at which litter fall and subsequently decay are thus important in understanding the productivity and nutrient budgeting of these agroforestry systems (Isaac 
and Nair, 2006). However, data on the quantity of litter fall, decomposition and nutrient release from Jatropha curcas are not known. This paper seeks to assess the litter production, decomposition and nutrient release pattern of Jatropha curcas used in an agroforestry system to ensure sustainability of the system.

Hypothesis and specific objectives: The hypothesis for this study is that the establishment of Jatropha curcas in an agroforestry system would not be sustainable in terms of litter fall and nutrient release into the system.

The objectives of the study were therefore to:

i. Determine the quantity of litter produced by Jatropha curcas L. at different plant spacing.

ii. Determine the trend of decomposition of Jatropha curcas leaves in closed and open canopies

iii. Determine the macro nutrients remaining in the decomposed leaf litter overtime.

\section{MATERIALS AND METHODS}

Study area: The experiment was conducted at the Faculty of Forest Resources Technology, Sunyani, Ghana $\left(7.35^{\circ} \mathrm{N}\right.$ and $\left.2.34^{\circ} \mathrm{W}\right)$ at an elevation of $360 \mathrm{~m}$ during July, 2008 to June, 2009. The soil texture was silt loam. The soil is classified as ferric acrisols (FAO Classification).

The area has a double rainfall regime with major rainfall from March to September and minor rainfall from October to February. Mean annual rainfall and temperature are $1300 \mathrm{~mm}$ and $26{ }^{\circ} \mathrm{C}$ respectively. Monthly rainfall figures and temperature recorded during the study period are presented in figure 1 and 2 respectively. From July to October, 2008 rainfall was relatively high and ranged from $81.5-154.4 \mathrm{~mm}$. From November 2008 to December 2008 rainfall figures were relatively low (Figure 1). Temperatures of between $28.7-30.5^{\circ} \mathrm{C}$ was recorded from July to October, 2008. The months of November 2008 to December 2008 recorded $31.3-33.5^{\circ} \mathrm{C}$ (Figure 2).
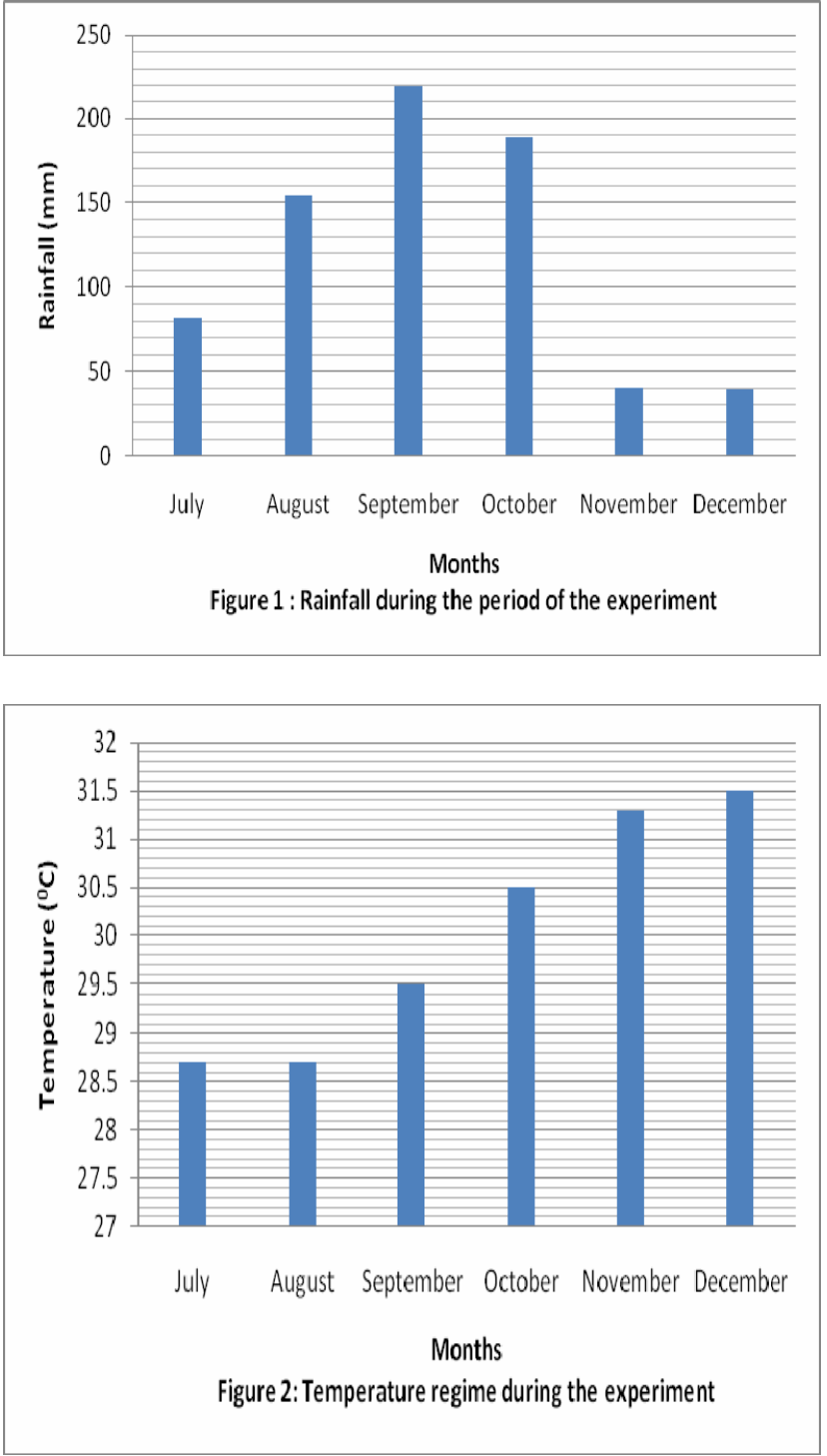

Litter collection of Jatropha curcas:

Litter collection was done from July, 2008 - June, 2009 for every two weeks. A total of fifteen (15) litter traps were placed for each treatment at various planting distance $(1 \mathrm{~m} \times 1 \mathrm{~m}, 2 \mathrm{~m} \times 1 \mathrm{~m}$, and $3 \mathrm{~m} \times 1 \mathrm{~m})$. A $2 \mathrm{~mm}$ nylon mesh size fitted to stakes fixed at $1 \mathrm{~m}$ $x 1 \mathrm{~m}$ in the ground was used as litter traps. The traps were raised above the ground and placed beneath Jatropha curcas canopies. The litters were then put in the oven at $60^{\circ} \mathrm{C}$ for 72 hours to measure the monthly dry matter weight of the litter. 
Decomposition of Jatropha curcas leaf litter: Decomposition of leaf litter of Jatropha curcas was determined over four (4) months under two different environments (closed and open canopy). Freshly fallen (green) leaves of Jatropha curcas were collected and placed in litter bags. Oven dry leaves were not used due to the risk of their rapid disintegration during the major rainfall event, which may lead to accelerated rates of decomposition (Anderson and Ingram, 1993). Use of fresh leaves is also more representative of natural decay process.

Eighty grams air dried litter of Jatropha curcas were weighed into $0.30 \times 0.30 \mathrm{~m}$ nylon litter decomposition bags with a 2-mm mesh size. A total of five litter decomposition bags spaced $0.50 \mathrm{~m}$ apart were placed along a transect on the surface of the soil. Each transect was replicated four (4) times ( $0.50 \mathrm{~m}$ spacing) for each area. A total of 40 litter bags were used for the study.

At the same time as litter decomposition bag placement, a set of leaves (4 replications) of Jatropha curcas was collected to determine initial dry matter weight. Samples of Jatropha curcas were taken to the Soil Research Institute where the initial concentration of $\mathrm{C}, \mathrm{P}, \mathrm{K}, \mathrm{N}, \mathrm{Ca}$ and $\mathrm{Mg}$ were determined. The decomposed litter was oven- dried at $60^{\circ} \mathrm{C}$ for 72 hours and then weighed. This material was ground in electric mill and stored in air-tight containers at room temperature. Carbon was determined by LECO carbon analyzer. Total Nitrogen was determined using the Kjeldahl method. $\mathrm{Ca}$ and $\mathrm{Mg}$ were estimated using the EDTA titration method. Phosphorus was determined by the Spectrophometric vanadium phosphomolybdate method whilst Potassium was estimated using the Atomic Absorption Spectrophometer.

A total of four litter decomposition bags per each environment were collected on days $30,60,90$ and 120. At each retrieval date, litter decomposition bag contents were carefully examined and all foreign materials including soil particles and leaves from weeds were removed. Soil was removed by brushing and briefly rinsing the leaves with distilled water (Anderson and Ingram, 1993).

The remaining residue was dried for 48 hours at $60^{\circ} \mathrm{C}$. Dried leaves were weighed and recorded as residue remaining and expressed as a percent residue remaining of the initial dry matter weight. The samples in the litter bags were also analyzed at monthly intervals for $\mathrm{C}, \mathrm{N}, \mathrm{P}, \mathrm{K}, \mathrm{Mg}$ and $\mathrm{Ca}$ to portray the nutrient release pattern from decaying litter. Samples in the fifth month were so negligible and could not be sent to the laboratory for analysis. Half-life of the species was calculated using the following formula;

$\mathrm{T}_{1 / 2}=\mathrm{T} \times \log 2$

$$
\log A m t B
$$$$
\text { Amt E }
$$

Where $T_{1 / 2}$ is the half-life of the species

$T$ is the Elapsed Time

Amt $B$ is the Beginning Amount

Amt $E$ is the Ending Amount

The decay constant $(k)$ was estimated by fitting the mass loss to single negative exponential models (Robertson and Paul, 2000) using the function $X_{t}=$ $\mathrm{X}_{0} \mathrm{e}^{-\mathrm{kt}}$, where $\mathrm{X}_{\mathrm{t}}$ is the remaining litter weight at time $t, X_{0}$ is the initial litter weight, $e$ is the natural logarithmic constant, $\mathrm{k}$ is the decay rate constant, and $\mathrm{t}$ is the time in days.

Data were statistically analyzed using the Genstat Discovery Edition 2 software. The analysis of variance (ANOVA) was used to determine significant difference between the treatments. The treatments were separated using the Least Significant Difference (LSD at $\mathrm{P}=0.05$ ).

\section{RESULTS}

\section{Litter fall of Jatropha curcas at different spacing}

The total quantity of litter produced in a year at different spacing was 2.27 ton/ha, 1.10 tons/ha and 0.79 tons/ha for $1 \mathrm{~m} \times 1 \mathrm{~m}, 2 \mathrm{~m} \times 1 \mathrm{~m}$ and $3 \mathrm{~m} \times 1 \mathrm{~m}$ respectively. Jatropha curcas exhibited two peaks of litter fall during the year (Figure 3). The month of November had the highest litter fall for all the treatments. The highest litter fall of $(508.8 \mathrm{~kg} / \mathrm{ha}$, $170.9 \mathrm{~kg} / \mathrm{ha}$ and $151 \mathrm{~kg} / \mathrm{ha}$ ) was for $1 \mathrm{~m} \times 1 \mathrm{~m}, 2 \mathrm{~m}$ $\times 1 \mathrm{~m}$ and $3 \mathrm{~m} \times 1 \mathrm{~m}$ respectively (Figure 3 ). The second peak of litter fall was in July where $1 \mathrm{~m} \times 1 \mathrm{~m}$ had the highest (Figure 3).

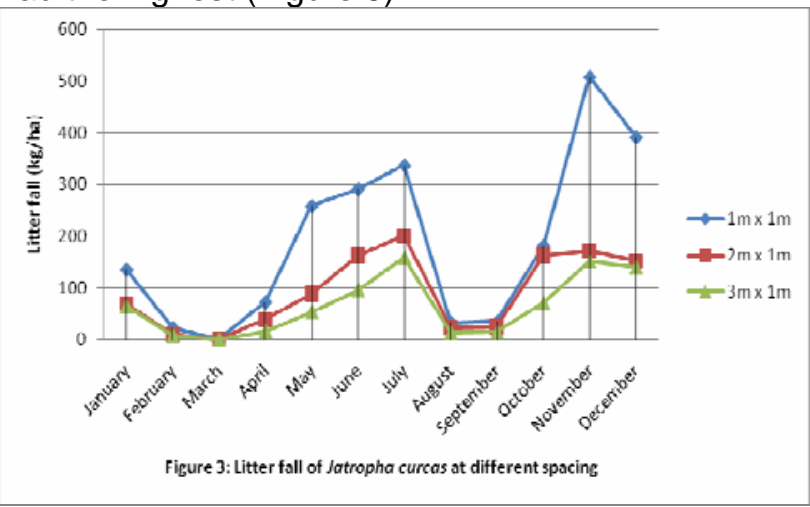


Initial dry matter and moisture content of Jatropha curcas leaves

The initial composition of the Jatropha curcas leaves were as follows:

Fresh weight:

$80 \mathrm{~g}$

Dry matter weight: $\quad 14.7 \mathrm{~g}$.

Dry matter (\%): $\quad 18.38$

Moisture content (\%): 81.62

\% lignin: $\quad 12.03$

\% Tannin: $\quad 2.90$

Litter decomposition patterns of Jatropha curcas:

The results obtained for the different environmental conditions reveal a significant loss of mass over time, which differs significantly between the treatments. Remnant litter mass was significantly smaller in open canopy compared to closed canopy.

The lowest residual litter mass recorded from open canopy, was significantly less than the remains of Jatropha curcas under closed canopy. It had 97$99 \%$ of the leaf litter decomposing at the end of the experimental period (four months) (Figure 4).

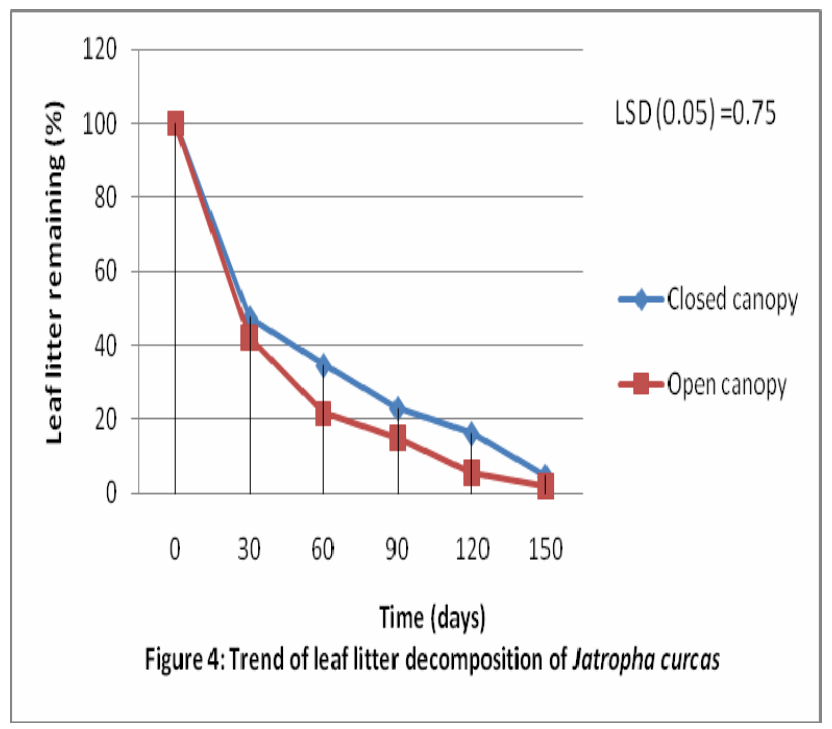

Half-life and Decomposition constant of Jatropha curcas

From Table 1, the half-life of decaying leaves of Jatropha curcas was 25 days in open canopy and 32 days in closed canopy. The decomposition constant for open and closed area were 0.020 and 0.0154 for open canopy and closed respectively (Table 1 ).

Nutrient dynamics in decomposed litter

$\mathrm{Ca}, \mathrm{Mg}, \mathrm{P}, \mathrm{K}, \mathrm{N}$ and $\mathrm{C}$ contents in the residual undecomposed leaf showed significant variations between the different environmental conditions. A higher proportion of the nutrients remain under closed canopy than open canopy. The pattern of nutrients in residual litter for $\mathrm{Ca}, \mathrm{Mg}$, and $\mathrm{K}$ under the two environmental conditions declined with time. A pattern of an increase followed by decrease was noticed for phosphorus. The $\mathrm{C} / \mathrm{N}$ ratio increased initially followed by a decline and then a further increase in both treatments (Table 2 and 3). In the closed canopy, a similar pattern of nutrients retained in residual litter was observed as in open canopy (Table 2). The same trend was observed in the C/P ratio where there was an initial decline at 30 days and then increased at 60 days followed by a decline at 90 days in both environmental condition (Table 2 and 3).

Table 1: Half-life of Jatropha curcas under open canopy and closed canopy

\begin{tabular}{|l|l|l|l|}
\hline Species & Area & $\begin{array}{l}\text { Decomposition } \\
\text { constant (k) }\end{array}$ & Half -life (days) \\
\hline Jatropha curcas & Open canopy & 0.020 & 25 \\
\hline Jatropha curcas & Closed canopy & 0.0154 & 32 \\
\hline
\end{tabular}


Table 2: The concentrations of $\mathrm{C}, \mathrm{N}$ and $\mathrm{P}$ in residual leaf litter Jatropha curcas in open canopy.

\begin{tabular}{|l|l|l|l|l|l|}
\hline Time(days) & $\mathrm{P}(\%)$ & $\mathrm{C}(\%)$ & $\mathrm{N}(\%)$ & $\mathrm{C} / \mathrm{N}$ ratio & C/P ratio \\
\hline 0 & 0.15 & 42.29 & 2.53 & 16.72 & 282 \\
\hline 30 & 0.32 & 23.81 & 1.02 & 23.34 & 74.4 \\
\hline 60 & 0.19 & 16.49 & 1.23 & 13.41 & 86.79 \\
\hline 90 & 0.06 & 31.5 & 1.32 & 23.86 & 525 \\
\hline 120 & 0.03 & 34.6 & 1.32 & 26.21 & 1153 \\
\hline
\end{tabular}

Table 3: The concentrations of $\mathrm{C}, \mathrm{N}$ and $\mathrm{P}$ in residual leaf litter Jatropha curcas in closed canopy.

\begin{tabular}{|l|l|l|l|l|l|}
\hline Time(days) & $\mathrm{P}(\%)$ & $\mathrm{C}(\%)$ & $\mathrm{N}(\%)$ & $\mathrm{C} / \mathrm{N}$ ratio & C/P ratio \\
\hline 0 & 0.15 & 42.29 & 2.53 & 16.72 & 282 \\
\hline 30 & 0.29 & 14.91 & 1.26 & 11.83 & 51.41 \\
\hline 60 & 0.06 & 16.33 & 1.51 & 10.81 & 271.16 \\
\hline 90 & 0.23 & 2.55 & 0.35 & 7.28 & 11.09 \\
\hline 120 & 0.13 & 2.45 & 0.26 & 9.43 & 18.8 \\
\hline
\end{tabular}

The percentage of calcium remaining in residual litter increased at 30 days and then declined sharply at 90 days for both treatments (Figure 5). Magnesium exhibited a different pattern in open canopy. The percentage of magnesium remaining in the leaf litter at 60 days increased and subsequently declined sharply at 90 days (Figure 6). Potassium exhibited the same pattern of nutrients remaining in litter for both open and closed canopy. Within the first 30 days the percent of $\mathrm{K}$ remaining declined sharply (Figure 7).

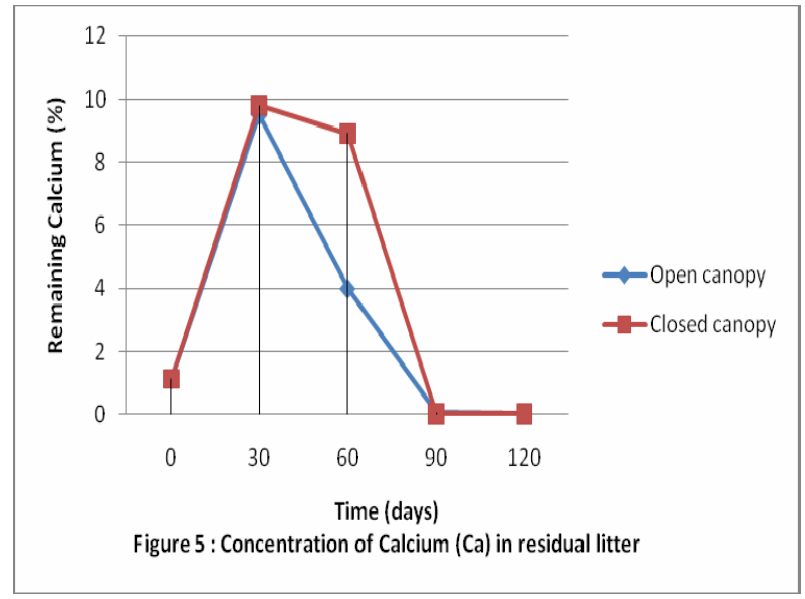

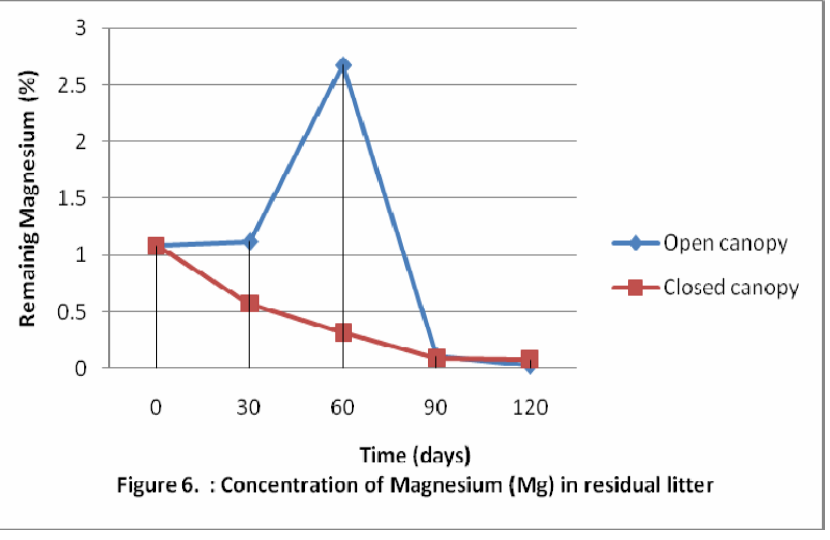

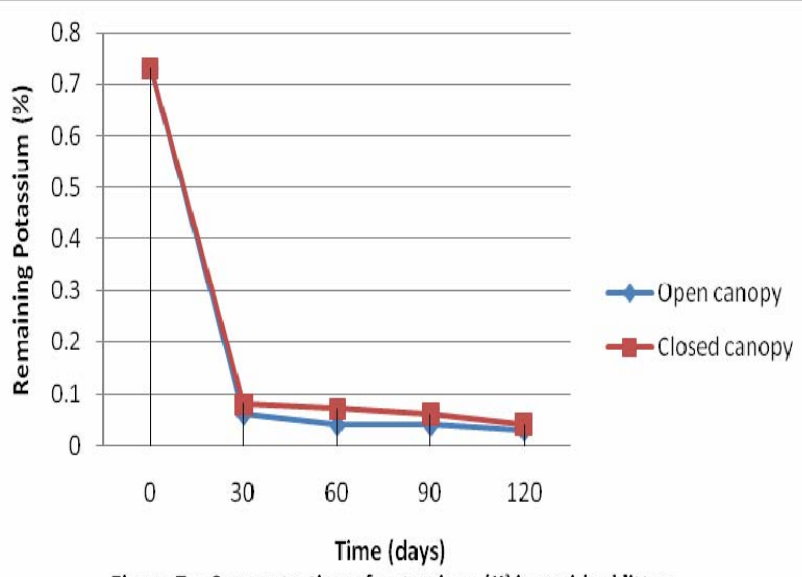

Figure 7 : Concentration of potassium (K) in residual litter 


\section{DISCUSSION}

Litter fall of Jatropha curcas: Maximum litter fall was in the dry season, where rainfall was low. This greatly reduced soil moisture extraction thereby reducing competition with crops for water and nutrients during the period. The highest litter fall recorded in November is similar to that reported by Jamaludheen and Kumar (1999) and Isaac and Nair (2006) in which litter fall was associated with natural senescence of leaves induced by temperature and/or moisture stress in the region (Isaac and Nair, 2006). This is evidenced from Figure 1 and 2 where the temperature was high and moisture low. The high litter production during this dry period will ensure soil cover and protection from excessive heat of the dry season as well as maintain nutrient cycling as highlighted by Montagnini et al. (1993). The pattern of litter fall could be taken advantage to synchronize the nutrient release with crop production in an alley cropping system. The total quantity of litter produced in a year at different spacing were 2.27 ton/ha, 1.10 tons/ha and 0.79 tons/ha for $1 \mathrm{~m} \times 1 \mathrm{~m}, 2 \mathrm{~m} \times 1 \mathrm{~m}$ and $3 \mathrm{~m} \times 1 \mathrm{~m}$ respectively. This quantity of litter fall was generally low. Beer (1988) reported annual litter fall rates of $2.9-3.3$ tons/ha for Cordia alliodora, 6.9 tons/ha for Inga jinicuil and 5.3 ton/ha for Inga leptoloba, all grown as shade trees for crops in humid tropical regions of Latin America at comparable densities of 185 - 278 trees/ha.

Pattern of leaf litter decomposition of Jatropha curcas in closed and open canopies: The direct exposure to radiation of leaf litter exerted a significant effect on the decomposition processes in open areas. Open canopy always had the highest litter-mass losses and fastest leaf-litter decay compared to those recorded in the shade. The results obtained suggest the effect of direct exposure of leaf litter to solar radiation is important in decomposition processes. Solar radiation on bare soils dehydrated plant material faster facilitating its mechanical destruction. This confirms what Wagner (1998) said that physical factors such as temperature influences decomposition. Like all living things bacteria and other decomposers have an optimal operating temperature. Far below this temperature, decomposition will be slow because bacteria and other decomposers have a greatly lowered metabolism or cannot survive and die (Wagner, 1998). Normally the warmer it is the more bacteria will thrive. Similar results have been obtained in other experiments. Laura and Yolanda (2007) in an experiment on spatial variability in decomposition rates in a desert scrub of Northwestern Mexico found that leaf litter exposed to radiation decomposed faster compared to those under the canopy of nursed trees. According to Gallardo and Merino (1993) litter decomposition rates are frequently considered to be regulated by soil organism, chemical nature of litter and environmental conditions especially soil moisture and relative humidity which are important in litter decay as these are regulated by by biological activity in the soil.

It was observed that leaf litter decayed faster during the wet period than during the dry period. Differences in water availability determined differences in decomposition trends and patterns of litter-mass losses. From August to October where the amount of rainfall was high, decomposition of leaf litter under open canopy was high than under closed canopy (Figure 4). From November to January 2009 decomposition trends of Jatropha curcas was slow under open canopy with those under closed canopy. This means that water is also a physical factor that plays a key role in decomposition rates. The wetter the soil the more decomposition occurs. Water is typically a limiting factor for many of the organisms that affect decomposition. The more water present the faster material will be broken down to a certain point. When the amount of water becomes too much decomposition rate becomes slower as was experienced under the canopy of trees during the wet period. The amount of water present can therefore greatly influence the rate of decomposition (Goulden, 2005). Rapid mass loss during the first month of decomposition could be the result of microbial utilization of highly labile compounds of the substrate, such as non-structural carbohydrates. When these are depleted the rate of mass loss is also decreased (McClaugherty and Berg, 1987). In field studies Prescott et al. (1993) reported that the labile fraction of litter was rapidly metabolized by microorganism or lost through leaching. Parson et al. (1990) however explained that although some of the labile material may be water soluble, microorganism metabolism rather than leaching is responsible for the greatest part of mass loss. Reinerstsen et al. (1984) associated the more rapid decay immediately after residue burial with the decomposition of water-soluble organic contents. Hunt et al. (1988) explained differences in decomposition pattern and rates among substrate as related to the amount of labile or rapid decomposing fractions (sugars, starches, proteins) and the 
recalcitrant or slowly decomposing fraction (cellulose, lignin, fats, tannins and waxes).

\section{Nutrient dynamics in decomposing litter}

Different nutrients in decomposing litter have different pattern of release overtime and that nutrients are retained with different strength in litter structures (Girisha et al., 2003). One mechanism for this according to Rutigliano et al. (1998) is microbial immobilization. The nutrients that are limiting or nonlimiting to microbial growth, determines its release dynamics. The nutrients which are limiting in amounts where carbon element ratio is above the critical level will be retained resulting in immobilization, whereas elements in surplus where the Carbon:element ratio is below the critical limit will be released during decomposition (Berg and Staff, 1981).

Nutrient dynamics of decomposing leaf litter showed nutrient contents of some elements in the residual litter to decline relative to the weight of litter. Potassium (K) release in open canopy and closed canopy was fast. In the case of open canopy it lost almost $92 \%$ in the first 30 days. Potassium in plants occurs mainly in soluble ionic form (Tukey, 1970). Potassium can therefore be easily leached from litter and losses may be accelerated by high rainfall. Potassium for example is highly mobile in plant, and is easily lost by leaching. The release pattern agrees with the review on potassium dynamics of decaying litter given by Stohlgren (1988); Toky and Singh (1993).

Phosphorus $(P)$ concentration in decomposing leaf litter was irregular in both open canopy and closed canopy. Phosphorus was immobilized in litter during the first 30 days and mineralization occurred at 60 days. There was an initial increase followed by a decline and an increase. In decaying leaf litter phosphorus may increase or decrease, the former being attributed to microbial immobilization (Bockheim et al. 1991). Quality of factors known to control phosphorus availability patterns of organic inputs are total $\mathrm{P}, \mathrm{C}: \mathrm{P}$ ratios and $\mathrm{N}: \mathrm{P}$ ratios (Vogt et al., 1986), which are highly variable in terms of the critical levels. Net mineralization ratios of $P$ from organic matter usually begins at C:P ratios $<200$ (Schlesinger, 1997). In the case of this study, C:P ratio where less than 200 except at 120 days (Table 6.2). Phosphorus immobilization may be due to the low initial $P$ concentrations in plant residues (Budelman, 1988).
An initial decline in nitrogen $(\mathrm{N})$ within the first 30 days was observed under both environmental conditions, which means a release of nitrogen into the soil. Nitrogen was immobilized at 60 days and dropped afterwards. Nutrients such as nitrogen which is often limiting to microbial growth are immobilized when the carbon supply is plentiful and nutrient concentrations are low and mineralized when carbon content decreases and nutrient concentration increases (O'Connell, 1988).

The pattern of magnesium $(\mathrm{Mg})$ release from the litter material was different between open canopy and closed canopy. In open canopy, $\mathrm{Mg}$ was immobilized at 60 days. The pattern of nutrient loss under closed canopy was gradual. This indicates a complex interplay of different processes during the decomposition. The amount of nutrients released depends on the intrinsic materials quality and amount of organic materials in the mulch (Cattanio et al., 2008).

Calcium (Ca) was immobilized at 30 days during the period of the study. Subsequently calcium was released into the soil. The period of immobilization was probably due to the to the luxury uptake of calcium into the fungal hyphae as documented by Swift et al. (1981).

C:N ratio and decomposition of Jatropha curcas leaf litter: The highest decomposition trend obtained for Jatropha curcas is probably caused by the relatively low $\mathrm{C} / \mathrm{N}$ value (Table 2 and 3 ). The theory of the $\mathrm{C}$ : $\mathrm{N}$ ratio is a representation of this principle. This says that organic matter with a low $\mathrm{C}$ to $\mathrm{N}$ ratio will decompose faster than a material with a high $\mathrm{C}: \mathrm{N}$ ratio. This theory states that nitrogen is normally the limiting factor for many of the organism populations. With a higher amount of nitrogen (a low C: $\mathrm{N}$ ratio) these populations are more free to grow rapidly and to higher concentrations, because of the nutrient cycling through the decomposing leaves (Knops, 2003).

Decaying plant tissue has varying amounts of cellulose, lignin, and hemicellulose, all high sources of Carbon. Carbon is the primary food for microbes, providing energy for their life processes. As dying plant material is introduced to the soil surface, microbes begin the degradation process using available nitrogen to break down the carbon for food and releasing $\mathrm{CO}_{2}$ and $\mathrm{NH}_{4}$ as by-products. The microbes ingest nutrients and additional carbon and nitrogen through immobilization. The lower the ratio, the more nitrogen is available and the quicker 
decomposition and mineralization. A ratio of $15: 1$ or higher may not have enough nitrogen available. This forces the microbes to pull in inorganic nitrogen from the soil, slowing mineralization down. Any ratio over $30: 1$ is considered extremely high and can result in some soil nitrogen deficiencies. The microbes, which tend to be more competitive than the plant, will completely exhaust the nitrogen resources in the soil. Depending on the $\mathrm{C}: \mathrm{N}$ ratio, this could go on for a considerable length of time (Brady, 1990). Similar results have been obtained in several researches. In an experiment on the decomposition of Erythrina peoppigiana leaves in alleycropping systems in Costa Rica, Oelbermann et al (2004) found the decomposition rate of the species to be high due to its low $\mathrm{C} / \mathrm{N}$ ratio.

K- values and Half life of Jatropha curcas: K-value is primarily controlled by climate and litter quality. Higher k-values correspond to faster rates of decomposition, while lower values correspond to slower rates decay. K-value is a function of temperature and moisture. Climates that are warm and wet have an increase the $\mathrm{k}$-value. It is for this reason that the open canopy had a higher k-value and lower half life.

\section{CONCLUSION}

Litter production and decomposition are important pathways of biogeochemical nutrient cycling in plantations. The results of the study have contributed to our understanding the litter dynamics of Jatropha curcas in our plantation development activities. The total quantity of litter produced in a year at different spacing were $2.27 \mathrm{ton} / \mathrm{ha}, 1.10$ tons/ha and 0.79 tons/ha for $1 \mathrm{~m} \times 1 \mathrm{~m}, 2 \mathrm{~m} \times 1 \mathrm{~m}$ and $3 \mathrm{~m} \times 1 \mathrm{~m}$ respectively. Decomposition trends were higher under open canopy and during the wet period than under closed canopy of trees. Leaf litter of Jatropha curcas was reincorporated faster into the soil. It had $97-99 \%$ of the leaf litter decomposing at 120 days. A litter decomposition and nutrient release pattern of Jatropha curcas was variable. Nutrients were immobilized when there was a lower concentration in leaf litter. Based on the results obtained Jatropha curcas proved to be important as nutrient source than as mulch.

\section{ACKNOWLEDGEMENT}

I am very grateful to the Agroforestry Practices to enhance Resource Poor livelihood Project funded by CIDA for supporting this research as part of my PhD program.

\section{REFERENCES}

Agarwal, A. K. (2007) Biofuels (alcohols and biodiesel) applications as fuels for internal combustion engine program. Energy combust Sci. 33: $233-271$.

Anderson, J.M. and Ingram, J. S. I. (1993) Tropical soil biology and fertility: $A$ handbook of methods $C A B$ International, Wallingford, UK, pp. 12.

Beer, J.W. (1988) Litter production and nutrient cycling in coffee (Coffea Arabica) and Cacao (Theobroma cacao) plantations with shade trees. Agroforestry systems 7: 103 - 114. In: Anglaere L.C.N. (2005) Improving the sustainability of cocoa farms in Ghana through utilization of Nature forest in agroforestry systems. PhD thesis. Uniiversity of Wales, Bangor, UK.

Berg, B. and Staaf, H. (1981) Leaching, accumulation and release of nitrogen in decomposing forest litter. Ecological Bulletin 33: 163 - 178. Anglaere L.C.N. (2005) Improving the sustainability of cocoa farms in Ghana through utilization of Nature forest in agroforestry systems. PhD thesis. Uniiversity of Wales, Bangor, UK.

Bockheim J. G., Jepsen E.A. and Heisey D. M. (1991). Nutrient dynamics in decomposing leaf litter of four tree species on a sandy soil in north western Wisconsin. Can. J. For. Res. 21:803-812 Botkin, D. B. (1993) Forest Dynamics: An Ecological Model. Oxford :Oxford University Press pp 44-48.

Buldelman, A. (1988). The decomposition of leaf mulches of Leucaena leucocephala, Gliricidia sepium, and Flemingia macrophylla under humid tropical conditions. Agroforestry Systems 7:33-45; 47-62.

Brady, N. C. (1990) "Soil Organic Matter and Organic Soils." In The Nature and Properties of Soils. 10th ed. New York: Macmillan. pp 22-28.

Cattanio, J. H., R. Kuehne and P.L.G. Vlek (2008) Organic material decomposition and nutrient dynamics in mulch system enriched with leguminous trees in the Amazon. R.Bras. Ci. Solo 32: 1073 - 1086.

Girisha, G. K., Condron, L. M., Clinton, P.W. and Davis, M. R. (2003) Decomposition and nutrient dynamics of green and freshly fallen radiate pine (Pinus radiate) needles. Forest Ecology and management 179: 169 181.

Goulden C. (2005) Decomposition Rates of Forest and Steppe Vegetation. Retrieved on Dec 2, 2006 from http://www.hovsgolecology.org/04 research/Decompo sition

Hunt, H. W., Ingham, E. R., Coleman, D. C. and Reid, C. P. P. (1988) Nitrogen limitation of production and decomposition in praire, mountain meadow, and pine forest. Ecology 69: 1009 - 1016. 
Isaac, S. R. and M. A. Nair (2006) Litter dynamics of six multipurpose trees in a home garden in southern Kerala, India. Agroforestry Systems 67: 203 - 213.

Jamaludheen V. and M. B. Kumar (1999) Litter of multipurpose trees in Kerala, India: variations in the amounts, quality, decay rates and release of nutrients. Forest Eclogy Management 115: 1- 11.

Karmas, M.A. (1970) Litter production. In: Philipson J (ed) Method of study in soil ecology. UNESCO IBP, Genova, pp 139-143.

Knops, J. (2003). Plant Litter Decomposition. Retrieved on Dec 2, 2006 from http://csp.unl.edu/public/G_decomp.htm.

Laura A. and Yolanda M. (2007) Spatial variability in decomposition rates in a desert scrub of Northwestern Mexico. Plant Ecology. Springer Science + Business Media B.V pp 213-225

McClaugherty, C. A. and Berg, B. (1987) Hollocellulose, lignin and nitrogen levels as rate regulating factors in late stages of forest litter decomposition pedobiologia 30: 101 - 112. In: Anglaere L.C.N. (2005) Improving the sustainability of cocoa farms in Ghana through utilization of Nature forest in agroforestry systems. PhD thesis. Uniiversity of Wales, Bangor, UK.

Montagnini, F., Ramstad, K. and Sandio, F. (1993) litter fall, litter decomposition and the use of mulch of four indigenous trees species in the lowlands of Costa Rica. Agroforestry system 23: $39-61$.

Mugendi, D. N., Nair, P. K. R., Mugwe, J. N., O'Neil, M. K., Swift, M. J. and Woomer, P. L. (1999) Alleycropping of maize with Calliandra and Leucaena in the subhunid highlands of Kenya: part 2: Biomass decomposition nitrogen mineralization and nitrogen uptake by maize. Agroforestry Systems 46: $51-64$.

O'Connell, A. M. (1988). Nutrient dynamics in decomposing litter in Karri (Eucalyptus diversicolor F. mill) forest of south-western Australia. J. Ecol. 76: 1186 - 1203. In: Cattanio, J. H., R. Kuehne and P.L.G. Vlek (2008) Organic material decomposition and nutrient dynamics in mulch system enriched with leguminous trees in the Amazon. R.Bras. Ci. Solo 32: 1073 - 1086.

Oelbermann M., Voroney R. P., Schlonvoigt A.M. and Kass D.C.L (2004) Decomposition of Erythrina peoppigiana leaves in 3-, 9-, and 18-year-old alleycropping systems in Costa Rica Agroforestry Systems 63:27-32

Parsons, W. F. J., Taylor, B.R. and Parkinson, D. (1990). Decomposition of aspen (Populus tremuloides) leaf litter modified by leaching. Canadian Journal of Forest Research 20: 943 - 951. In: Anglaere L.C.N. (2005) Improving the sustainability of cocoa farms in Ghana through utilization of Nature forest in agroforestry systems. PhD thesis. Uniiversity of Wales, Bangor, UK.
Prescott, C.E., Taylor, B.R., Parsons, W.F.J., Durall, D.M. and D. Parkinson (1993) Nutrient release from decomposing litter in rocky mountain coniferous forest; Influence of nutrient availability. Canadian Journal of Forest Research 23: 1576 - 1586. In: Anglaere L.C.N. (2005) Improving the sustainability of cocoa farms in Ghana through utilization of Nature forest in agroforestry systems. PhD thesis. Uniiversity of Wales, Bangor, UK.

Reinerstsen, S. A., Elliot, L. F., Cochran, V. L. and Campbell, G. S. (1984) Role of available carbon and nitrogen in determining the rate of wheat straw decomposition. Soil biology, Biochemistry 16: 459 464.

Robertson, G. P. and E. A., Paul (2000) Decomposition and soil organic matter dynamics. In: Laura A. and Yolanda M. (2007) Spatial variability in decomposition rates in a desert scrub of Northwestern Mexico. Plant Ecology. Springer Science + Business Media B.V pp 213-225

Rutigliano, F. A., Alfani, A., Bellini, L. and Desanto, V.A. (1998) Nutrient dynamics in decaying leaves of Fagus sylvatica L. and needles of Abies alba mill. Biology and fertility of soil 27: 119 - 126. In: Anglaere L.C.N. (2005) Improving the sustainability of cocoa farms in Ghana through utilization of Nature forest in agroforestry systems. PhD thesis. Uniiversity of Wales, Bangor, UK.

Stohlgren, T. J. (1988) Litter dynamics in two sierra mixed conifer forests. Litterfall and decomposition rates. II. Nutrient release in decomposing leaf litter. Can. J. For. Res.: $1127-1144$.

Swift, M. J. and Heal O.W, Anderson J.M (1979) Decomposition in terrestrial ecosystems. Studies in Ecology, vol 5. University of California Press, California pp 12-15.

Tukey, H. B. (1970). The leaching of substances from plants. Ann. Rev. Plant Physiology 21: 305 - 324.

Vogt, K. A., Grier, C. C. and Vogt, D. J. (1986) Production, turnover and nutrient dynamics of above and below ground detritus of world forests. Adv. Ecol. Res. 15: 303 - 377. In: Cattanio, J. H., R. Kuehne and P.L.G. Vlek (2008) Organic material decomposition and nutrient dynamics in mulch system enriched with leguminous trees in the Amazon. R.Bras. Ci. Solo 32: $1073-1086$.

Wagner, A. (1998). The Decomposition Process. Retrieved Nov 16th, 2006 from http://aggiehorticulture.tamu.edu/extension/compost

Young, A. (1997). Agroforestry for soil management, effect of trees on soils. CAB International, Wallingford, UK pp 23,214 . 